\title{
Globalization and labor market outcomes: de-industrialization, job security, and wage inequalities-introduction by guest editor
}

\author{
Sébastien Lechevalier ${ }^{1}$
}

Published online: 21 May 2015

(C) Kiel Institute 2015

The impact of globalization-through foreign direct investment (FDI) and international trade - on domestic labor markets is a very active field of research, at the intersection of international economics and labor economics. In particular, it has led economists to revisit the analysis of the determinants of wage inequality by focusing on the heterogeneity of corporate international engagement (Baumgarten 2013; Ito and Lechevalier 2009). This research also addresses the causes of increasing employment insecurity and the impact on inequalities through this channel (Geishecker 2008). More generally, it is central to the analysis of structural changes in labor markets and in the design of public policies to tackle them.

This special issue of the Review of World Economics consists of seven papers presented in their preliminary versions at a workshop held in April 2013 at the National Graduate Institute for Policy Studies (GRIPS), in Tokyo, Japan. ${ }^{1}$ This is one of the products of a 3 year research project entitled "De-industrialization and the future of industries in Japan, Korea, Germany, and France" coordinated by the Fondation France-Japon de l'EHESS. One principle shared by the researchers, whose papers are gathered in this special issue, is that "de-industrialization" is a useful concept to study the impact of globalization on domestic labor markets, providing that it is not restricted to changes in the employment structure (e.g., reduction in the share of manufacturing employment in total employment) but also includes the analysis of various indicators of job "quality" (job security, job status, skill structure and wage inequalities, etc.), which have been relatively neglected by the literature or studied partially and separately. To put it differently, the issues at

\footnotetext{
1 The guest editor wishes to thank Professor Jun Suzuki for agreeing to host and organize this workshop.
}

Sébastien Lechevalier

Sebastien.lechevalier@ehess.fr

1 Ecole des Hautes Etudes en Sciences Sociales (EHESS), Paris, France 
stake are at least twofold and should not be studied separately from each other: What is the impact of international trade and FDI on the level and structure of domestic employment? Are OECD workers increasingly vulnerable in the global economy (OECD 2007)?

These two questions are investigated by comparing four countries that are not usually compared: Japan, Korea, Germany, and France. They have been selected for the following reasons. First of all, they have been relatively less studied than the US or the UK, and their analysis allows a comparison between European and Asian OECD members. Second, labor market outcomes in these four countries differ considerably. On the one hand, both Japan and Korea have experienced a surge of non-regular employment (which now represents approximately $35 \%$ of total employment in these two countries) and it is important to determine whether internationalization of these two economies may account for this phenomenon. On the other hand, although one observes a rather similar deterioration of employment conditions in Germany and France, labor market outcomes in these two countries are diverging, especially with respect to the unemployment rate, and it is interesting to assess whether this divergence may be driven by differences in the process of internationalization of firms. Finally, there are substantial differences with respect to strategies and business practices of multinational enterprises: the degree of offshoring varies in cross-country comparisons as does firms' organization and behavior (e.g., the dominance of large firms in France and Korea in global engagement contrasts with a greater role of small and medium enterprises in Germany and Japan, especially in production networks).

Another interest of this special issue is to provide empirical evidence based on recent data. The research presented employs not only sectoral datasets (Durand and Miroudot 2015) but also comparable longitudinal micro datasets (Kambayashi and Kiyota 2015; Laffineur and Mouhoud 2015; Görg and Görlich 2015; Lee and Lee 2015; Baumgarten 2015)—which are particularly useful to analyze labor market dynamics, and even a unique dataset from one particular division of an iconic Korean firm, Samsung (Lee and Jung 2015). The quality of data used allows the authors going (at least) one step further than the existing literature. For example, Baumgarten (2015) makes use of data not only on net flows but also on accessions and separations and that include information on skill level. Another example is Laffineur and Mouhoud (2015), which is able to use data on tasks at the individual level. The papers in this special issue deal with various aspects of the impact of FDI and international trade on domestic labor markets.

The first group of papers (Durand and Miroudot 2015; Kambayashi and Kiyota 2015; Lee and Jung 2015) directly deal with the issue of de-industrialization and reconsider the possible contribution of globalization, primarily through FDI. Durand and Miroudot (2015) provide an econometric analysis at the country and industry level of the relationship between globalization, financialization and employment over the period 1995-2009. Their results cannot be interpreted as evidence of a financial-led globalization; but rather they find that employment levels are reduced through the financialization observed in certain industries. The next two papers deal with the impact of outward FDI on the domestic labor market by adopting two complementarity perspectives. Kambayashi and Kiyota (2015) use Japanese data 
that allow them to decompose factor and final good prices for each destination country and therefore distinguish between international reallocation of labor and a substitution between labor and capital. Their results suggest that the reduction in employment in Japan has been driven mainly by the substitution of labor by capital, rather than by the reallocation of labor from Japan to other countries. Lee and Jung (2015) propose a "nano" investigation of Samsung's mobile phone division and examine the effects of establishing factories abroad on domestic jobs and the potential technological "hollowing out". It is shown that the "quality" of Samsung's domestic employment, measured by skill level demanded, has increased and associated wages have improved. Samsung's case suggests that what determines the level and trend of domestic employment is not whether the firms set up factories overseas but rather whether the firms are able to maintain their competiveness.

The second group of papers (Laffineur and Mouhoud 2015; Görg and Görlich 2015; Lee and Lee 2015) is concerned with the polarization that may be induced by a differential impact of globalization (mainly through FDI) on blue-collar workers and routine workers and white-collar workers/managers and non-routine-workers (Laffineur and Mouhoud 2015) or on temporary workers and permanent workers (Görg and Görlich 2015). Their results support concerns about the role of globalization in increasing inequalities. More precisely, Laffineur and Mouhoud (2015) analyze the effect of outward FDI on the composition of work in French firms. Their primary result is that FDI to low-income countries significantly raises the share of executives and reduces the share of blue-collar workers in company workforces in France, whereas outward FDI to high-income countries reduces the share of workers performing non-routine manual tasks. Görg and Görlich (2015) and Lee and Lee (2015) employ very similar methodologies. Görg and Görlich (2015) use the German Socio-Economic Panel (SOEP) linked to industry-level data on offshoring (1999-2007). They find a differential impact for different industries and different types of workers. In manufacturing industries core offshoring reduces wages of temporary workers and reduces risk of unemployment for all types of worker. In contrast, in service industries there is no wage effect while non-core offshoring reduces unemployment risk for all. Using a similar dataset for Korea to that which Görg and Görlich (2015) use for Germany, Lee and Lee (2015) find that the impact of offshoring differs not only by souring country but also by type of contract. Offshoring to OECD countries is generally beneficial to South Korean workers but temporary workers do not fully enjoy the benefits. As for offshoring to non-OECD countries, it is found to reduce the real wages of temporary workers.

The last paper included in this special issue, Baumgarten (2015), investigates the impact of the international trade involvement of an establishment on employee flows by using a linked employer-employee dataset for Germany. It provides evidence of a process of polarization at work. More precisely, it is shown that establishments trading internationally have lower worker turnover rates than nontraders, suggesting a higher degree of employment stability.

All papers have passed through the usual peer review process for the Review of World Economics, and all authors would like to thank the anonymous referees for their helpful comments that have hopefully much improved the contributions to this 
issue. Furthermore, the guest editor wishes to thank the managing editor, Professor Harmen Lehment, for his continuous support in preparing this special issue.

\section{References}

Baumgarten, D. (2013). Exporters and the rise in wage inequality: Evidence from German linked employer-employee data. Journal of International Economics, 90(1), 201-217.

Baumgarten, D. (2015). International trade and worker flows: empirical evidence for Germany. Review of World Economics/Weltwirtschaftliches Archiv, 151(3). doi:10.1007/s10290-015-0216-y (this issue).

Durand, C., \& Miroudot, S. (2015). Is labor the fall guy of a financial-led globalisation? A cross-country inquiry on globalisation, financialisation and employment at the industry level. Review of World Economics/Weltwirtschaftliches Archiv, 151(3). doi:10.1007/s10290-015-0217-x (this issue).

Geishecker, I. (2008). The impact of international outsourcing on individual employment security: A micro-level analysis. Labour Economics, 15(3), 291-314.

Görg, H., \& Görlich, D. (2015). Offshoring, wages and job security of temporary workers. Review of World Economics/Weltwirtschaftliches Archiv, 151(3). doi:10.1007/s10290-015-0220-2 (this issue).

Ito, K., \& Lechevalier, S. (2009). The evolution of the productivity dispersion of firms-A reevaluation of its determinants in the case of Japan. Review of World Economics/Weltwirtschaftliches Archiv, 145(3), 405-429.

Kambayashi, R., \& Kiyota, K. (2015). Disemployment by Foreign Direct Investment? Multinationals and Japanese Employment. Review of World Economics, 151(3). doi:10.1007/s10290-014-0205-6 (this issue).

Laffineur, C., \& Mouhoud, E. M. (2015). The jobs at risk from globalization: The French case. Review of World Economics/Weltwirtschaftliches Archiv, 151(3). doi:10.1007/s10290-015-0221-1 (this issue).

Lee, K., \& Jung, M. (2015). Overseas factories, domestic employment and technological hollowing-out. A case study of Samsung's mobile phone business. Review of World Economics/Weltwirtschaftliches Archiv, 151(3). doi:10.1007/s10290-015-0219-8 (this issue).

Lee, H., \& Lee, J. (2015). The impacts of offshoring on temporary workers: Evidence on wages from South Korea. Review of World Economics/Weltwirtschaftliches Archiv, 151(3). doi:10.1007/s10290015-0215-z (this issue).

OECD. (2007). Employment outlook. OECD Publishing. doi:10.1787/empl_outlook-2007-en. 